\title{
ESTABLISHMENT OF BLUE MUSSEL BEDS TO ENHANCE FISH HABITATS
}

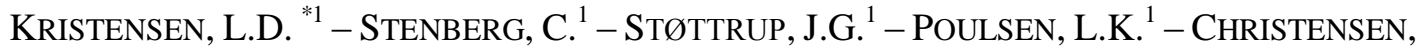 \\ H.T. ${ }^{1}$ - DOLMER, P. $^{1}$ - LANDES, A. ${ }^{1}-$ RøJBEK, M. ${ }^{1}-$ THORSEN, S.W. ${ }^{2}-$ HOLMER, M. ${ }^{2}$ - DeURS, \\ M.V. ${ }^{3}-$ GRøNKJÆR, P. ${ }^{4}$ \\ ${ }^{1}$ Technical University of Denmark, National Institute of Aquatic Resources, \\ Joegersborg Allé 1, 2920 Charlottenlund, Denmark. \\ (phone: +45-3588-3300; fax: +45-3588-3333) \\ ${ }^{2}$ University of Southern Denmark, Department of Biology, \\ Campusvej 55, 5230 Odense M, Denmark. \\ (phone: +45-6550-2752; fax: +45-6550-2786) \\ ${ }^{3}$ Nordshell, Bergmannsvej 26, 5700 Svendborg, Denmark. \\ (phone: +45-2630-1224) \\ ${ }^{4}$ Aarhus University, Department of Bioscience - Aquatic Biology, \\ Ole Worms Allé 1, 8000 Aarhus, Denmark. \\ (phone: +45-8715-0000; fax: +45-8715-4326) \\ *Corresponding author \\ e-mail: LKR@aqua.dtu.dk \\ (Received $8^{\text {th }}$ Jan 2015; accepted $9^{\text {th }}$ Feb 2015)
}

\begin{abstract}
Human activity has impacted many coastal fjords causing degeneration of the structure and function of the fish habitats. In Nørrefjord, Denmark, local fishermen complained of declining fish catches which could be attributed to eutrophication and extraction of sediments over several decades. This study aimed to establish blue mussel beds (Mytilus edulis) to increase structural complexity and increase the abundance of fish and epifauna in Nørrefjord. It was expected that the mussels would improve water transparency and increase the depth range and coverage of eelgrass (Zostera marina). New methods for mussel production and -bed construction were investigated in collaboration with local volunteer fishermen. The effect of the artificial mussel beds was most evident on a small scale. Video observations directly at the beds (Impact area) demonstrated increased biodiversity and a three times higher abundance of mesopredator fish compared to the Control area. Water clarity and eelgrass coverage were unchanged. Two methods for establishing mussel beds were tested. A total of 44 tons of blue mussels were produced and established in beds over an area of $121,000 \mathrm{~m}^{2}$. Production of blue mussels directly on hemp sacs hanging on long-lines was the most effective method. This new method is potentially a useful management tool to improve fish habitats.
\end{abstract}

Keywords: habitat complexity, biogenic reef, fish community, benthos, volunteer.

\section{Introduction}

Coastal habitats are under great anthropogenic pressure and $85 \%$ of the European coastlines are estimated to be degraded (Bryant et al., 1995; EEA, 1999). Eutrophication, overfishing and destructive dredging fishery have severely affected shellfish and biogenic reefs (Airoldi and Beck, 2007). These pressures may also affect the population structure of fish (Sundblad et al., 2014) as the coastal habitats are important for many commercial fishes for spawning, feeding and as nursery area (Seitz et al., 2014). 
Habitat complexity in coastal habitats is an important component for a number of fish species as more complex bottom structures provide more shelter opportunity from predators and a higher abundance of prey than bare bottom sediments (Heck and Wetstone, 1977; Luckhurst and Luckhurst, 1978; Nelson and Bonsdorff, 1990). The abundance and biodiversity of fauna living within a biogenic reef of bivalves, increase with complexity and structure area, and promotes fish growth and diversity (Carbines et al., 2004; Norling and Kautsky, 2007; 2008). Especially smaller fish species such as common goby (Pomatoschistus microps), rock goby (Gobius paganellus) and butterfish (Pholis gunnellus) but also larger fish like flatfishes use mussel beds as habitat for either direct foraging, breeding or as nursery area (Jones and Clare, 1977). Predatory fish are attracted to the structures by the abundance of prey. The overall effects of increased complexity can thus be relatively substantial for fish. Apart from improving coastal habitats by increasing the complexity (McDermott et al., 2008), mussels are filter feeders and remove suspended inorganics, phytoplankton and detrital particles. The filtration process reduces turbidity and generally improves water quality (Riemann et al., 1988; Nielsen and Maar, 2007). The improved water transparency leads to better conditions for benthic primary producers e.g. sea grasses (Newell and Koch, 2004), allowing them to spread into deeper areas.

Nørrefjord, Denmark, is representative for many coastal areas in northern Europe. It has been subject to substantial nitrogen loadings from agriculture during the last three to four decades (Rask et al., 2000). High nitrogen loadings are known to reduce water transparency and increase the extent and frequency of oxygen depletion events (KrauseJensen et al., 2011; 2012; Wulff et al., 2014). However, in the last decade, nitrogen loading has dropped markedly in Nørrefjord, whereas phosphorous has remained unchanged but at a low level (data, The Danish Natural Environment Portal, miljoeportal.dk) due to intensive improvements in sewage treatment during the $1980 \mathrm{~s}$ (Ærtebjerg et al., 2003). Further, the fjord has experienced extraction of sand and gravel from 1950-1990 (N.C. Christensen, local fisherman, pers. com.). Extraction of resources from shallow coastal areas reduces the complexity of the bottom and the habitat quality (Nielsen and Petersen, 2013). In other coastal areas in Denmark, dredging activities with towed fishing gears for fin- and shellfish (Dolmer and Frandsen, 2002; Kaiser et al., 2006) also deteriorate habitat quality. Furthermore, climate change, increased water temperature and acidification may impact coastal habitats (IPCC, 2014; Mackenzie et al., 2014). All these pressures have resulted in deteriorated habitats and a decline in bottom fauna and fish biomass (Pihl et al., 2005; Holm, 2005; Christiansen et al., 2006). Nørrefjord was previously dominated by blue mussel beds (Rask et al., 2000) but hypoxia events is believed to have degraded the benthic habitats with an associated decline in fish populations. This general deterioration of the fjord is of great concern to the local recreational fishermen, who experience declining fish catches. The recreational fishermen therefore initiated this project to improve conditions for fish by promoting fish habitats in Nørrefjord. This project is unique through the close collaboration between local stakeholders, local managers and researchers.

Bivalve restoration is known to have a positive effect on fish communities (reviewed by Peterson et al., 2003). Most studies focus on oyster beds, but the function of structure is more important than the species comprising the structure (Palomo et al., 2007; Norling and Kautsky, 2007). Therefore it was hypothesized that establishment of mussel beds could, in a manner similar to oyster beds, improve fish habitats. When establishing cultured mussels, it is standard procedure to dredge natural bottom mussels for seeds 
and then transplant the mussels to a different area from a specialized vessel (Dolmer et al., 2012). Neither the destructive dredging nor the expensive machinery was an option in this project in Nørrefjord.

The primary aim of this study was to test if establishment of blue mussel beds would have a positive effect on abundance of fish and epifauna. It was also hypothesized that the established mussel beds would improve water transparency followed by increase in eelgrass (Zostera marina) depth range and coverage. The secondary aim was to develop an efficient and effective method for production of suspended blue mussels for the establishment of bottom mussel beds in a Danish fjord using voluntary labour, as this had not been attempted before.

\section{Materials and Methods}

\section{Study area}

The field study was conducted during 2010 and 2011 in Nørrefjord, Helnæs Bight (10 7.17E 55 9.10N) south-west of the Island of Funen, Denmark (Fig. 1). The fjord is a protected bay with two connections to the strait Lille Belt between Funen and the Jutland Peninsula. The mean water depth is $5.5 \mathrm{~m}$ and the maximum depth is $12 \mathrm{~m}$ (Rask et al., 2000). Two sites resembling each other in terms of depth, sediment and eelgrass cover were chosen $1 \mathrm{~km}$ apart, one was the Control and one was the Impact area (Fig. 1).

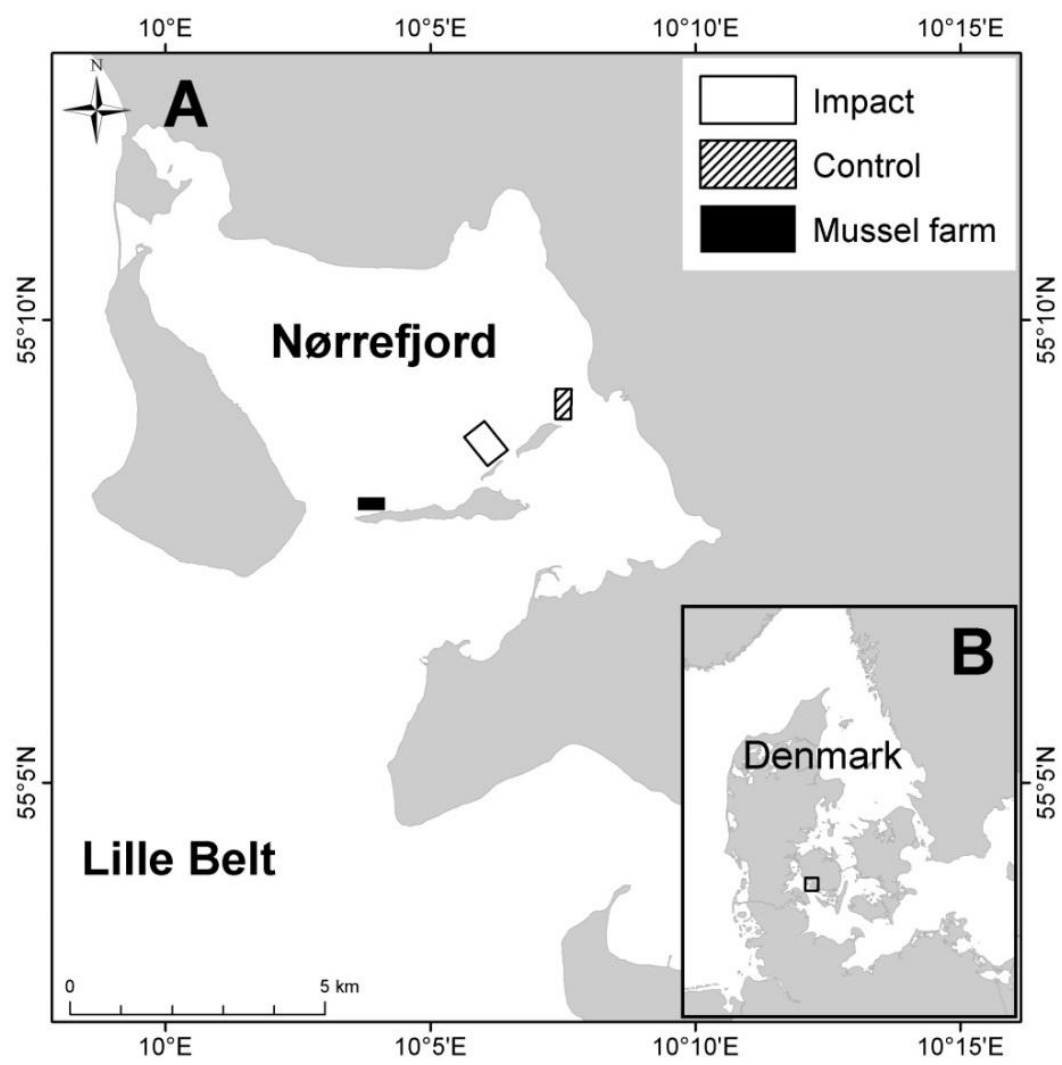

Figure 1. Study area. A) Location of the mussel farm, the Impact area, and the Control area. B) Location of Nørrefjord in Denmark. 


\section{Establishment of blue mussel beds}

A mussel collection site (mussel farm) was established with help from a local consultant (Nordshell A/S) (Fig. 1). The mussel farm consisted of long-line systems (7 x $200 \mathrm{~m}$ length) maintained floating by gradually increasing the number of buoys as the weight of the produced mussels increased over the summer.

Blue mussel beds were established on the fjord bottom at 4-6 m depth within the Impact area (Fig. 2a). The mussel beds where constructed to increase the complexity of the bottom substrate to improve the beds' value as fish habitat. The overall bed structure was constructed in a patchy distribution to imitate natural mussel beds. The mussel beds were constructed as piles of $1 \mathrm{~m}$ diameter and $0.5 \mathrm{~m}$ height (= one mussel bed). This was done by piling $28 \mathrm{~kg}$ of mussels on top of degradable hemp sacks through a tube (40 $\mathrm{cm}$ diameter, $6 \mathrm{~m}$ length). Half the piles were placed on top of 3 hemp sacks (60$100 \mathrm{~L}$ ) containing mussel shells (40 L per sac), thus producing 3-dimensional structures on the seafloor. Another $25 \%$ of the piles consisted of mussels placed directly on the fjord bottom without hemp sacks. The remaining $25 \%$ consisted of hemp sacks with mussel shells. All mussel beds were placed in grids with 3-10 m distance between single beds resulting in a mussel density of $2.8-9.3 \mathrm{~kg}_{\text {mussel }} \mathrm{m}^{-2}$.

\section{Effect analysis}

Before commencing the effect analysis, diver and video observations were made to estimate the survival rate of the blue mussels and to confirm that the structures still remained on the fjord bottom. No systematic analysis was made based on diver and video observations. However, a rough estimate of the mussel survival rate was found based on the observations.

The effect of the constructed mussel beds was measured in a BACI design, including investigations before mussel bed establishment (summer of 2010) and one year after mussel bed establishment (summer of 2011). All analysis took place in both control and impact area. The effect analysis sought to clarify the effect of the mussel beds on fishes, epibenthic invertebrates and important environmental parameters presented in the following sections.

\section{Eelgrass and water quality}

Eelgrass coverage in the Impact area and Control area was mapped 1) to locate areas suitable for mussel bed establishment and 2) to analyse the effect of the mussel beds on eelgrass coverage before and after mussel bed establishment (Table 1, Fig. 2). Eelgrass coverage was mapped by in situ video monitoring of the fjord bottom from a slow drifting boat. GPS position of the drop camera (600 TV lines) and the associated eelgrass coverage was logged every 2 min. Eelgrass coverage was analysed in 5 categories: $0=$ no eelgrass, $1=$ dead shoots, $2=$ single plants, $3=$ thin coverage or patches, $4=$ dense beds of eelgrass. These categories corresponded to a percentage cover of $0=0 \%, 1=0 \%$ (dead shoots), $2=1-25 \%, 3=26-75 \%, 4=75-100 \%$. Mussel beds were placed in areas within the Impact area where there was, generally, no eelgrass to avoid damaging eelgrass beds.

The effect of the mussel beds on water transparency was investigated by measuring secchi depth, and measurements were carried out weekly from May to September before and after mussel bed establishment. 


\section{Epibenthic samples}

Benthic invertebrates were quantified in the Control area and Impact area before and after mussel bed establishment using an epibenthic sledge (Modified Ockelman Sledge, KC Denmark, Denmark) (Table 1). The sledge was dragged $30 \mathrm{sec}$ at $1 \mathrm{kn}$ over the seafloor at 4-6 randomly selected stations in the two areas, in the depth range of mussel bed establishment (4-6 m), to sample invertebrates and other smaller organisms living on the surface of the bottom substrate. The density of all fauna was estimated based on the area covered by the sledge on each tow $\left(4.6 \mathrm{~m}^{2}\right)$. All organisms were counted and determined to lowest possible taxonomical group. Fish, blue mussels and snails were not included in this analysis as they could not be quantified properly from sampling with the epibenthic sledge.
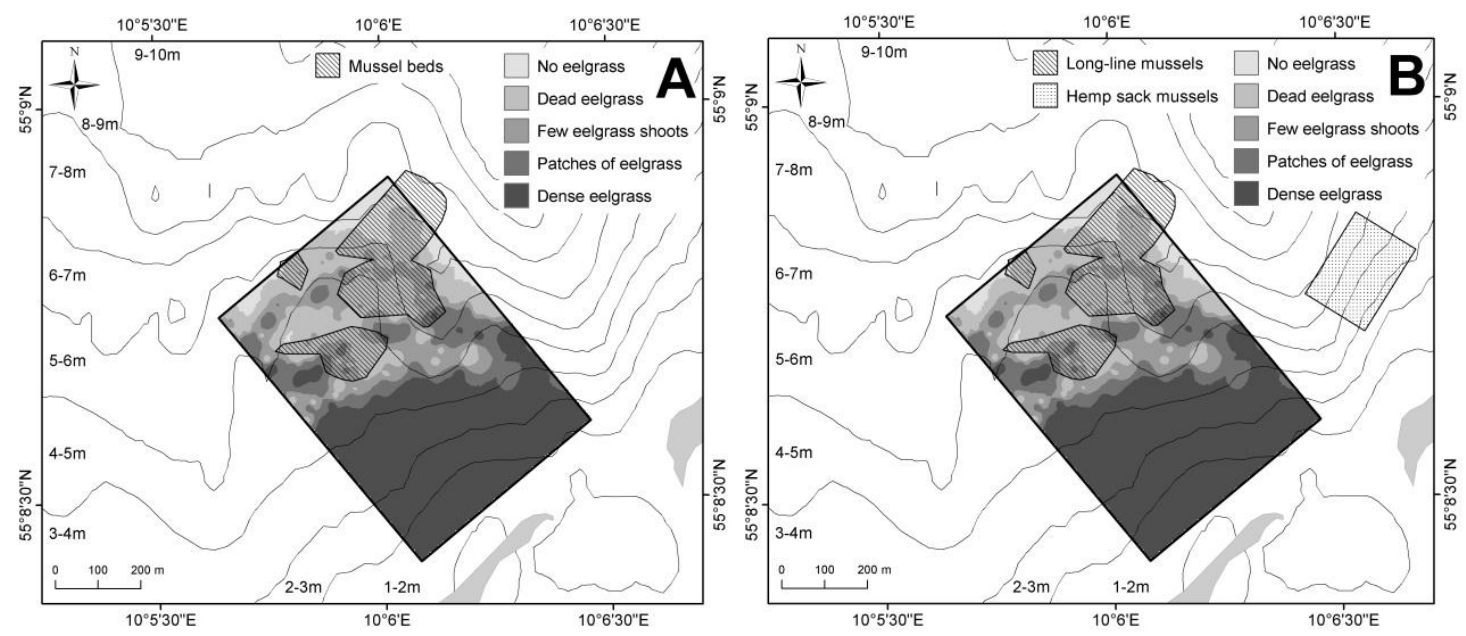

Figure 2. A) Mussel beds were established in Impact area. B) Two different methods of blue mussel production and establishment of mussel beds were tested in 2010 and 2011, respectively. Eelgrass cover is based on data from 2010.

\section{Fish community}

Fish distribution and abundance was investigated using two different methods 1) gillnets for large scale effect of the mussel beds on the fish community (0-100 m) and 2) video observations for small scale effect $(0-2 \mathrm{~m})$. Gillnets were deployed at 9 stations in the Control and Impact area with 3 stations at 0-2 m, 2-4 m and 4-6 m depth (Table 1). Each station was sampled once a month from May to October before and after mussel bed establishment, using multi mesh size gillnets. The mesh sizes in the different panels were $6.5,8.5,11,14.3,18.6,24.2,31.4,40.9,53.1,69,89.7$ and $116.6 \mathrm{~mm}$ and applied in random order during sampling. Height of the nets were $1.5 \mathrm{~m}$ and length was $3 \mathrm{~m}$ (mesh size 6.5-14.3 mm), $6 \mathrm{~m}$ (mesh size 18.6-40.9 mm), or $12 \mathrm{~m}$ (mesh size 53.1-116.6 $\mathrm{mm}$ ) (Eigaard et al., 2000). All nets were deployed in the afternoon and hauled the following morning. The catch was identified to species level, and total length was measured to the nearest $0.5 \mathrm{~cm}$ below and weighed $( \pm 1 \mathrm{~g}$ wet weight). No differentiation was made between sprat/herring, salmon/trout and common/sand goby.

Two cameras (Sport, LH Camera, Denmark) recorded close-up of the mussel structures in the Impact area and sandy bottom in Control area both at 4-5 m depth (Table 1). The cameras recorded continuously for $12 \mathrm{~h}$. All video sampling was carried 
out in late summer after mussel bed establishment in five consecutive days. Subsequently, fish appearance was counted for every second minute for the first 10 minutes of each hour. The remaining video sequences were viewed but not analysed. To avoid bias from the deployment operation, the first $30 \mathrm{~min}$ after deployment of the camera was omitted.

\section{Development of new method}

The local community of recreational fishermen (Danish Organization for Amateur Fishermen in Faaborg) contributed to the project on a volunteer basis and did most of the practical work (i.e. crowdsourcing).

Mussel beds were established in 2010 and 2011 with two different methods. In 2010 blue mussels were produced in a mussel farm on suspended long-lines and harvested from a specialized vessel in November 2010. The harvested mussels were thereafter used to establish mussel beds in the Impact area as described above (Fig. $2 b)$. In 2011 blue mussels were produced directly on hemp sacks (100 L) filled with $40 \mathrm{~L}$ of shells hung from the long-line system. The mussel beds were then constructed in September 2011 outside the Impact area by transporting the long-line with the hemp bags between two boats to the Impact area. The mussel bags were then detached from the line and allowed to sink to their placement with approximately the same distance between the bags as in 2010. The effect of the second mussel bed establishment 2011 was not investigated.

Table 1. Samples carried out in 2010 and 2011. For secchi depth, the first number represents the number of samples statistically analysed and the number in parenthesis is the actual number of samples.

\begin{tabular}{|c|c|c|c|c|c|}
\hline \multirow[b]{2}{*}{ Sampling } & \multicolumn{2}{|r|}{2010} & \multicolumn{3}{|c|}{2011} \\
\hline & Control & \begin{tabular}{|c|} 
Impact \\
Off structure On structure
\end{tabular} & Control & $\begin{array}{r}\text { Im } \\
\text { Off structure } \\
\end{array}$ & $\begin{array}{l}\text { act } \\
\text { On structure }\end{array}$ \\
\hline Epibenthic sledge & 4 & 6 & 5 & 5 & \\
\hline Gillnet & 54 & 54 & 54 & 54 & \\
\hline Video obs. & & & $11 \mathrm{~h}$ & & $23 \mathrm{~h}$ \\
\hline Eelgrass cover & $701 \mathrm{obs}$ & 1201 obs & $501 \mathrm{obs}$ & 591 obs & \\
\hline Secchi depth & $0(31)$ & $0(30)$ & $14(99)$ & 14 (106) & $11(22)$ \\
\hline
\end{tabular}

\section{Data analysis and statistics}

Secchi depth: The difference between average secchi depths was analysed in the Control area, Impact area and directly on the mussel bed area in 2011. Only averages on days where secchi depth was measured in all 3 areas or minimum in Control and Impact area were included in the analyses to ensure that the differences were caused by area and not by time. Data was tested using a GLM (model: area + day) where area was either Control or Impact and day was a random effect.

Eelgrass: The difference in eelgrass coverage was tested at 4-6 m depth (mussel bed establishment depth) with logistic regression. The independent variable in the model was eelgrass coverage with category values between 0 to 4 while the dependent variables were areas (Control, Impact) and years (2010 (before), and 2011 (after)).

Epibenthic Samples: Using the BACI design (Underwood 1992) ensured that any 
detected changes found were a result of the establishment of blue mussel beds and not temporal or spatial variability. Standardized cross effect of Control-Impact and beforeafter was estimated by LSmean function in proc-GLM (model: Year*Area). Abundance data were log-transformed. The following variables were used: year (2010 and 2011), area (Control and Impact) and species.

Fish Community: Standardized cross effect of BACI was estimated by LSmean function in proc-GLM (Abundance model: Year*Area). Abundance data were logtransformed. The following variables were used: year (2010 and 2011), area (Control and Impact), species (the most dominant species was analysed separately while the remaining species were grouped into "Other species"), depth (0-2 m, 2-4 m and 4-6 m), low/high impact area (0-4 m and 4-6 m) and season (May+Jun, Jul+Aug and Sep+Oct).

The abundance of fish pr. video sequence followed a negative binomial distribution and data was analysed for any effects of area and time of day by LSmean function in proc-GLM (abundance $=$ area month hour). Data were log-transformed and observations were divided into morning (8:00-11:00), noon (12:00-15:00) and evening (16:00-19:00).

The threshold for rejection of the null hypothesis was defined as $\mathrm{P}=0.05$. Data was statistically analysed in SAS 9.4.

\section{Results}

\section{Establishment of blue mussel beds}

The naturally occurring blue mussel beds in Nørrefjord were generally in poor condition consisting primarily of empty, crushed shells and very few live mussels. The natural beds were small $(<5-7 \mathrm{~m}$ in diameter) and occurred mainly from 4-6 $\mathrm{m}$. Therefore the produced blue mussels were established in beds to imitate the size and placement of natural mussel beds in other areas of Nørrefjord: 1-2 m diameter spaced 3$10 \mathrm{~m}$ apart at 4-6 m depth corresponding to $121.000 \mathrm{~m}^{2}$ of mussel bed in total (Fig. 2A).

A rough estimate based on diver and video observations showed that approximately $5 \%$ of the mussels had survived until spring of 2011. The structures of the beds were intact as the empty mussel shells still remained on the fjord bottom.

\section{Fish communities}

A total of 19 different fish species were caught in gillnets in 2010 and 15 in 2011. In both years the catches were dominated by three species: cod (Gadus morhua) black goby (Gobius niger) and three-spined stickleback (Gasterosteus aculeatus), which combined accounted for $81 \%$ of the total catches. The statistical tests focused on these three species, as all other species occurred in low numbers (Table 2) and were combined in the category "Other species" for statistical testing.

On the video recordings 112 primarily smaller fish were observed in both areas in 2011. Seven taxonomical groups were recorded (Table 2) and goby was the most common group represented by black, sand and undetermined goby comprising approximately $66 \%$ of the observations in the Impact area. Undetermined species comprised $29 \%$ of the catches but was most likely from the Gobiidae family. Only one fish species was observed in the Control area and four species were observed in the Impact area, disregarding the goby sp. and unidentified fish species.

A significant cross effect on fish abundance of year and area, i.e. a direct effect of mussel bed establishment was only found for black goby at $0-4 \mathrm{~m}$ depth $(\mathrm{P}=0.004-\mathrm{se}$ 
all P-values in Table 3). The mean abundance of black goby decreased from 4.7 to 0.2 ind. day ${ }^{-1}$ in the Control area and from 5.2 to 0.02 ind. day $^{-1}$ in the Impact area from 2010 to 2011.

Yearly variation in abundance was significant for cod, black goby and three-spined stickleback in both 0-4 m depth and 4-6 m depth (all $\mathrm{P}<0.05$ ), with an increase in cod and three-spined stickleback and decrease in black goby from 2010 to 2011. A significant effect of area was only observed for black goby $(\mathrm{P}=0.009)$. Significant changes in abundance caused by season were observed for cod in the 4-6 m depth and black goby in 0-4 and 4-6 m depth (Fig. 3). For all other fish species no significant changes were observed for any of the analysed variables.

Table 2. Abundance of fish species caught in gillnets and observed in video observations in the Control and Impact area.

\begin{tabular}{l|c|c|c|c}
\hline \multirow{2}{*}{ Scientific name } & $\begin{array}{c}\text { Gillnet catch } \\
\text { pr. day n }\end{array}$ & $\begin{array}{c}\text { Gillnet catch } \\
\text { pr. day n }\end{array}$ & $\begin{array}{c}\text { Video obs } \\
\text { pr. day n }\end{array}$ & $\begin{array}{c}\text { Video obs } \\
\text { pr. day }\end{array}$ \\
\cline { 2 - 5 } & $\begin{array}{c}\text { Control } \\
\mathrm{n}=108\end{array}$ & $\begin{array}{c}\text { Impact } \\
\mathrm{n}=108\end{array}$ & $\begin{array}{c}\text { Control } \\
11 \mathrm{~h}\end{array}$ & $\begin{array}{c}\text { Impact } \\
23 \mathrm{~h}\end{array}$ \\
\hline Agonus cataphractus & 0.3 & & & \\
Ammodytes tobian & 1.7 & 1.8 & & \\
Belone belone & 2.0 & 0.5 & & \\
Ctenolabrus rupestris & & & & \\
Eutrigla gurnardus & & 0.2 & & \\
Gadus morhua & 48.2 & 50.7 & & \\
Gasterosteus aculeatus & 109.3 & 149.2 & & \\
Gobius niger & 69.7 & 51.7 & & \\
Merlangius merlangus & 0.2 & & & \\
Myoxocephalus scorpius & 13.0 & 26.7 & & \\
Pholis gunellus & 0.2 & & & \\
Platichthys flesus & 3.3 & 2.5 & & \\
Pleuronectes platessa & 0.3 & 0.5 & & \\
Pomatoschistus minutus/microps & 6.3 & 4.8 & & \\
Salmo salar/trutta & 2.5 & 0.7 & & \\
Scomber scombrus & 3.5 & 4.5 & & \\
Spinachia spinachia & 9.0 & 4.0 & & \\
Sprattus sprattus/Clupea harengus & 12.5 & 4.7 & & \\
Syngnathus typhle & & 0.2 & \multirow{26.1}{*}{17.5} & \\
Zoarces viviparus & 6.7 & 16.7 & & \\
*goby & & & & \\
Undetermined & & & & \\
\hline Total & $\mathbf{2 8 8 . 7}$ & $\mathbf{3 1 9 . 2}$ & $\mathbf{4 1 . 5}$ & \\
\hline
\end{tabular}

There was a highly significant difference between the abundance of fish observed on video $(\mathrm{P}<0.0001)$ in the Impact area compared to the Control area, with three times as many fish observed directly on the mussel beds (Table 2). In addition to this, a diel variation occurred, as significantly more fish were observed in the morning compared to 
noon and evening $(\mathrm{P}<0.0001)$. There was no significant difference between noon and evening $(\mathrm{P}=0.19)$.

Outside the processed $5 \times 2$ minute observations, cod, trout and flatfish were observed on several occasions but only in the Impact area.

\section{Epibenthic samples}

In total, 14 taxa were recorded in epibenthic samples of which 9 were identified to species level (Table 4). Two of the taxa were fish (Sygnathus typhle and Pomatochistus microps) and one was blue mussel (Mytilus edulis). All three were omitted from the analysis leaving 11 taxa of benthic invertebrates in the analysis. Crustaceans dominated the community both in terms of numbers and taxa with 8 of the 11 invertebrate taxa.

Table 3. P-values for mean abundance of fish caught in gillnets. Significance levels are set at: *0.05,** 0.01,***0.001. The $\div$ for Gobius niger in Year*Area column at 0-4 m depth indicate that the cross effect of year and area was significantly negative for this species.

\begin{tabular}{|c|c|c|c|c|c|c|}
\hline Abundance & Impact & Year & Area & Year*Area & Season & Depth \\
\hline \multirow{2}{*}{ Gadus morhua } & $\begin{array}{l}\text { High (4-6 } \\
\text { m) }\end{array}$ & $* * *$ & $\mathrm{P}=0.2$ & $\mathrm{P}=0.1$ & $\mathrm{P}=0.8$ & - \\
\hline & $\begin{array}{c}\text { Low (0-4 } \\
\mathrm{m})\end{array}$ & $* * *$ & $\mathrm{P}=0.7$ & $\mathrm{P}=0.5$ & $* *$ & $\mathrm{P}=0.07$ \\
\hline \multirow{2}{*}{ Gobius niger } & $\begin{array}{l}\text { High (4-6 } \\
\text { m) }\end{array}$ & $* * *$ & $\mathrm{P}=0.1$ & $\mathrm{P}=0.1$ & $* * *$ & - \\
\hline & $\begin{array}{c}\text { Low }(0-4 \\
\mathrm{m})\end{array}$ & $* * *$ & $* *$ & $\div \quad * *$ & $* * *$ & $\mathrm{P}=0.8$ \\
\hline \multirow{2}{*}{ Gasterosteus aculeatus } & $\begin{array}{l}\text { High (4-6 } \\
\text { m) }\end{array}$ & $*$ & $\mathrm{P}=0.4$ & $\mathrm{P}=0.5$ & $\mathrm{P}=0.3$ & - \\
\hline & $\begin{array}{c}\text { Low }(0-4 \\
\mathrm{m})\end{array}$ & $* *$ & $\mathrm{P}=0.8$ & $\mathrm{P}=0.7$ & $\mathrm{P}=0.09$ & $*$ \\
\hline \multirow{2}{*}{ Other } & $\begin{array}{l}\text { High (4-6 } \\
\text { m) }\end{array}$ & $\mathrm{P}=0.9$ & $\mathrm{P}=0.4$ & $\mathrm{P}=0.6$ & $\mathrm{P}=0.07$ & - \\
\hline & $\begin{array}{c}\text { Low (0-4 } \\
\text { m) }\end{array}$ & $\mathrm{P}=0.8$ & $\mathrm{P}=0.1$ & $\mathrm{P}=0.6$ & $\mathrm{P}=0.4$ & $\mathrm{P}=0.06$ \\
\hline
\end{tabular}

Only one species in each of the taxonomical phylums Echinodermata, Annelida and Urochordata was found.

In general, year and area had an effect on abundance of most species of epibenthos. A positive significant effect of mussel beds on abundance was found for Polynoidae $(\mathrm{P}=0.04)$, Praunus flexuosus $(\mathrm{P}=0.04)$ and Idotea baltica $(\mathrm{P}=0.006)$ (cross effect of year and area) (Table 4). The abundance of Idotea increased only in the Control area, so the effect of mussel beds in the Impact area seems to be negative for this species. No significant effect of mussel beds was observed for all species suited as fish prey (all species except tunicate (Ascidiae) and starfish (Asterias rubens)) or all species combined.

Starfish increased 15 to 32 fold in the Impact and Control area, respectively, from 2010 to 2011 . All starfish were relatively small ranging from $4 \mathrm{~mm}$ to $9 \mathrm{~cm}$ with $70 \%$ measuring $<15 \mathrm{~mm}$. 
Table 4. Abundance of epibenthic invertebrates $m^{-2}$ in the Control and Impact area before (late October 2010) and after (early November 2011) mussel bed establishment. "- " signifies too few observations for statistical analysis. Significance levels are set at: *0.05, **0.01, $* * * 0.001$.

\begin{tabular}{|c|c|c|c|c|c|c|c|c|}
\hline \multirow{2}{*}{ Benthic invertebrates } & \multicolumn{2}{|c|}{$\begin{array}{c}2010 \\
\text { No }^{-2}\end{array}$} & \multirow{2}{*}{\multicolumn{2}{|c|}{\begin{tabular}{|cc}
2011 \\
No $^{-2}$ \\
Control \\
$\mathbf{n}=5$
\end{tabular}$\underset{n=5}{\text { Impact }}$}} & \multirow[t]{2}{*}{ Fish prey } & \multicolumn{3}{|c|}{ Significant changes } \\
\hline & $\begin{array}{c}\text { Control } \\
n=4\end{array}$ & $\begin{array}{c}\text { Impact } \\
n=6\end{array}$ & & & & Year & Area & Year*Area \\
\hline Crustacea & & & & & & & & \\
\hline Corophiidae & 1.2 & 2.3 & 0.3 & 4.7 & Yes & & $* *$ & \\
\hline Crangon crangon & 0.9 & 5.7 & 1.6 & 3 & Yes & & & \\
\hline Gammaridae & 2 & 1.4 & 0.3 & 20.1 & Yes & & & \\
\hline Idotea baltica & 0.1 & 2.8 & 17.4 & 3.3 & Yes & $* * *$ & & $* * *$ \\
\hline Ostracoda & 0 & 0 & 0 & 0 & Yes & - & - & - \\
\hline Palaemon adspersus & 2.3 & 2 & 0.3 & 0 & Yes & $* *$ & & \\
\hline Phtisica marina & 0 & 0 & 0.3 & 9.6 & Yes & $* * *$ & & \\
\hline Praunus flexuosus & 0.5 & 0.1 & 6.7 & 18.6 & Yes & $* * *$ & & $*$ \\
\hline Echinodermata & & & & & & & & \\
\hline $\begin{array}{l}\text { Asterias rubens } \\
\text { Annelida }\end{array}$ & 0.7 & 2.2 & 26.9 & 28.3 & No & $* * *$ & & \\
\hline $\begin{array}{l}\text { Polynoidae } \\
\text { Urochordata }\end{array}$ & 0.1 & 0 & 0.9 & 3.1 & Yes & $* *$ & & $*$ \\
\hline Ascidacea & 0 & 0.1 & 1 & 0.4 & No & $* * *$ & & \\
\hline n total & 8 & 16.5 & 55.9 & 91.3 & & $* * *$ & & \\
\hline n fish prey & 7.3 & 14.2 & 28 & 62.5 & & $* *$ & & \\
\hline
\end{tabular}

\section{Eelgrass and water quality}

All secchi measurements varied between 3.4 and $6.0 \mathrm{~m}$ with slightly deeper measurements during early summer compared to late summer as could be expected due to seasonal variation in planktonic blooms (data not shown). No significant difference was found between the Control and Impact area $(\mathrm{P}=0.36)$.

The restored mussel beds did not affect eelgrass coverage significantly when comparing eelgrass coverage in the Control area and Impact area in 2010 or 2011 ( $\mathrm{P}>0.05$, logistic regression). Neither were there significant differences when comparing areas with and without restored beds in the Impact area at 4-6 m depth (P>0.05, ChiSquare test). Depth was the only factor that had a significant effect on eelgrass coverage $(\mathrm{P}<0.0001$, Chi-Square test). Video observations of eelgrass cover showed dense mats until 4-5 m depth and a maximum depth of $7.4 \mathrm{~m}$ in both the Control and Impact area.

\section{Development of new method}

In 2010 the mussels were produced on suspended long-line systems. Based on mussel coverage, weight and long-line length in the mussel farm, it was estimated that a total of 28 tons of blue mussel were produced in 2010. The harvest and subsequently construction of mussel beds was labour-intensive and 14 men and 5 boats worked for 8 days. 

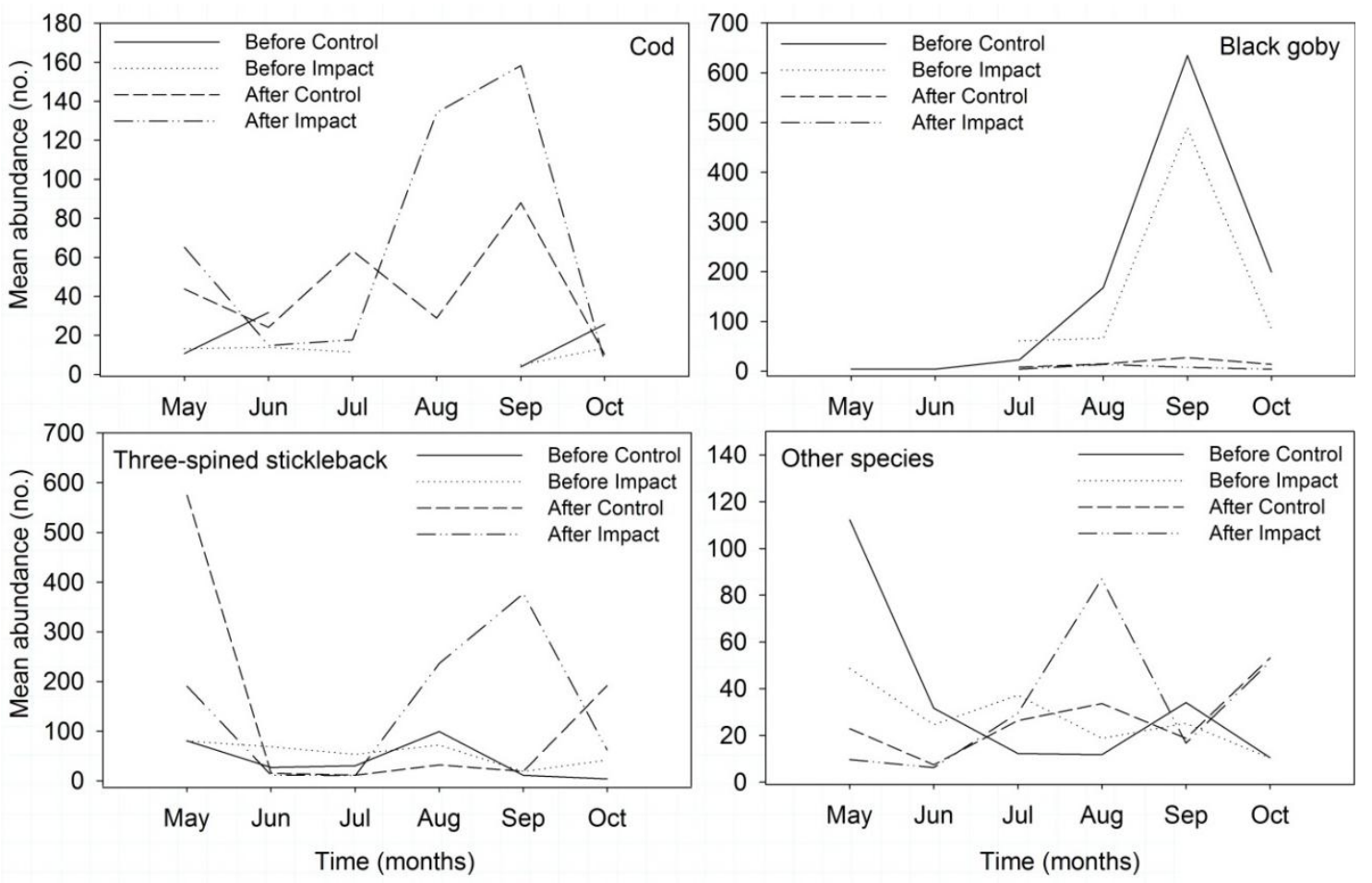

Figure 3. Monthly (May-Oct) fish catches for cod, black goby, stickleback and other species caught in gillnets in the Control and Impact area before and after mussel bed establishment.

Notice the difference in abundance between species.

To reduce the work load in the harvest process, blue mussels were in 2011 produced on hemp sacks on the long-lines. It was estimated that 16 tons of blue mussels were produced using this method. The harvest and construction of mussel beds required 12 men and 5 boats in 1 day.

\section{Discussion}

\section{Effect of mussel bed establishment}

The mussel bed structures improved fish habitat on a local scale resulting in a higher abundance and biodiversity of fish directly on the introduced mussel structures. In particular, small gobies were observed circling around the structures for extended periods. Similar observations were made around stone reefs and wind turbine foundations in the Baltic Sea where gobies were observed to occur in significantly higher numbers within a few meters from the structures (Wilhelmsson et al., 2006; Andersson and Öhman, 2010; Hansen, 2012). Also larger fish (e.g. cod) are known to be surprisingly stationary (Lindholm et al., 2007; Karlsen, 2011). The very local effect of structures could explain why the effect of the established mussel beds in the present study was greatest in the video observations rather than the larger scale gillnets and epibenthic sledge.

Very few mussels survived the starfish predation, but the structure remained intact as empty shells. The increase in starfish abundance in spring 2011 could not be related to the establishment of the mussel beds as the increase in starfish abundance occurred both 
in the Control and Impact area. High abundance of starfish was also reported from adjacent waters (Lille Belt) (pers. com. Allan Buch). The structures comprised by the empty mussel shells are reported to be just as important as live mussels as they still function as shelter for associated fauna (Palomo et al., 2007; Norling and Kautsky, 2007). In this study, the persistence of the local effect on fish abundance and biodiversity, despite the high predation rate by starfish on the blue mussels, supports the finding that the fish habitat function of the mussel bed remains intact with its structure, despite the loss of live blue mussels.

Gobies are mesopredators and attract larger piscivorous species, such as cod and trout (Fjøsne and Gjøsæter, 1996; Wennhage and Pihl, 2002; Almqvist et al., 2010). The observation of large piscivorous species (trout and cod) in the Impact area suggests that the same attraction mechanism was present around the established mussel bed structures. There was a tendency towards increased cod abundance after mussel bed establishment (Fig. 3). This increase in predation pressure could explain the decreased black goby abundance. We did not see the same decrease for three-spined stickleback. This may be due to the relatively large spines of the stickleback that make it a less attractive prey compared to the goby (Wennhage and Pihl, 2002).

The goldsinny wrasse (Ctenolabrus rupestris) is a fish species occurring in higher densities near rocky substrates and exhibits high affinity to these types of complex habitats (Gjøsaeter, 2002). The presence of goldsinny wrasse on the established mussel structures suggest that the mussel structure provided a complex habitat similar to rocky reefs that could attract this reef-associated species.

\section{Eelgrass and water quality}

The establishment of the mussel bed in the present study did not affect the eelgrass coverage or depth range. Eelgrass cover was generally in good condition in Nørrefjord with patches as deep as 7-8 $\mathrm{m}$ in depth. The reason for the good condition in Nørrefjord is probably the reduced nitrogen loading compared to the 1980s (data, The Danish Natural Environment Portal, miljoeportal.dk, Rask et al., 2000). The decrease in nitrogen loading has gradually increased the secchi depth (data, The Danish Natural Environment Portal, miljoeportal.dk) and improved the light conditions for eelgrass.

An effect on secchi depth after the establishment of the new mussel beds could not be expected due to the magnitude of the established mussel beds. A conservative estimate of potential filtration rate with $5 \%$ survival of the 28 tons mussels established in beds in autumn 2010 would be $5600 \mathrm{~m}^{3} \mathrm{~d}^{-1}$ (based on filtration rate for $25 \mathrm{~mm}$ blue mussels found by Winter, 1973). The total body of water in Nørrefjord is $213 \times 10^{6} \mathrm{~m}^{3}$ and according to maximum tidal amplitude, the exchanged body of water is estimated to $15.6 \times 10^{6} \mathrm{~m}^{3}$ twice a day, not taking into account any wind effect. Thus, even if all the mussels had survived, the filtration rate would have been $0.1 \times 10^{6} \mathrm{~m}^{3}$ and still not enough to filter the water body exchanged by the tide alone. However, other studies have demonstrated a depletion of phytoplankton around blue mussel long-line systems with up to $80 \%$ and up to $1.5 \mathrm{~m}$ increase in secchi depth (Petersen et al., 2013). It has been estimated that an increase in secchi depth of $12 \mathrm{~cm}$ in Skive Fjord (another Danish fjord resembling Nørrefjord in area and mean depth) could be achieved by 18.8 ha of mussels on suspended long-lines (Petersen et al., 2013). That is 13 times larger than the mussel farm used in Nørrefjord. As bottom living mussels experience depletion of food items due to less exchange of water near the bottom compared to suspended mussels (Petersen et al., 2013), Nørrefjord would need even more mussels and thus a larger 
proportion of the fjord bottom, to see the same change as for the suspended mussels studied in Skive Fjord. However, since an increase in secchi depth would in time increase macro algae and eelgrass depth range (Nielsen et al., 2002) the establishment of mussel beds in these areas may be one way to improve local environmental conditions in semi-enclosed fjords.

\section{Development of a new method}

The method with mussel production on hemp sacks on the long-lines followed by direct establishment of the mussel beds was the most effective method both in time and labour compared to the traditional long-line system. The hemp sack method can be applied to many other geographic locations. The heavy involvement of local volunteers can be recommended in future ecological improvement- and restoration projects. Crowdsourcing allowed us to conduct the experiment cost-effectively. As long as the projects evolve in collaboration with researchers and local managers, this development of bottom-up initiated projects may be beneficial to society and increase environmental awareness of the local community (Grese et al., 2000). The increased awareness was reflected in the wide interest in the project from local and regional newspapers, radio stations as well as the attendance at stakeholder meetings (Assens Municipality, Developing Fyn Municipal Ltd (Lag Fyn), The Danish Nature Agency of Odense, the Danish Ministry of the Environment and local interest organizations such as the sailing club and the Danish Organization for Amateur Fishermen). It was even suggested by the stakeholders that this collaboration with the local community should be best practice in all future habitat restoration projects.

\section{Conclusions}

In conclusion, this study showed that it was possible to improve fish habitats on a local scale. The blue mussel structures established in Nørrefjord improved shelter and food especially for small mesopredator fish. The quantity of blue mussels established in Nørrefjord was insufficient to observe any effect on secchi depth and eelgrass cover and range. A new method was introduced, as we succeeded to establish mussel beds in a cost-effective way using crowdsourcing (local volunteer fishermen). The hemp sacks attached to the long-lines proved to be the most effective method of the two methods tested.

This study shows that with the help of volunteers, this habitat improvement strategy is a potential useful management tool to increase fish abundance and improve fish communities in Danish fjords in the future. Therefore, we recommend more local involvement in future improvement and restoration projects.

Acknowledgements. The project was financed by the Ministry of Food, Agriculture and Fishery, Fisheries Local Action Groups FLAG Fyn, the European Fishery Fund and the Danish Marine Coastal Fisheries Management Program (Fiskepleje). The authors wish to thank the many volunteer fishermen for the invaluable contribution. Special thanks to Poul Erik Nielsen, Niels Christian Christensen, Bent Ingildsen and Vagn Gram. Also thanks to the tireless crew, Jesper Knudsen, Stine Kærulf Andersen, Nina Holm, Marianne Knudsen and last but not least a thanks to Kerstin Geitner for GIS assistance. 


\section{REFERENCES}

[1] Ærtebjerg, G., Andersen, J.H., Hansen, O.S. (eds) (2003): Nutrients and eutrophication in Danish marine waters. A challenge for science and management. Scientific Report. National Environmental Research Institute, Ministry of the Environment. Denmark.

[2] Airoldi, L., Beck, M.W. (2007): Loss, status and trends for coastal marine habitats of Europe. - In: Gibson, R., Atkinson, R.J.A., Gordon, J.D.M. (eds) Oceanography and marine biology: An annual review 45: 345-405.

[3] Almqvist, G., Strandmark, A.K., Appelberg, M. (2010): Has the invasive round goby caused new links in Baltic food webs? - Environmental Biology of Fishes 89: 79-93.

[4] Andersson, M.H., Öhman, M.C. (2010): Fish and sessile assemblages associated with wind-turbine constructions in the Baltic Sea. - Marine and Freshwater Research 61: 642650 .

[5] Bryant, D., Rodenburg, E., Cox, T., Nielsen, D. (1995): Coastlines at risk: an index of potential development-related threats to coastal ecosystems. - WRI Indicator Brief, World Resources Institute, Washington, DC.

[6] Carbines, G., Jiang, W., Beentjes, M.P. (2004): The impact of oyster dredging on the growth of blue cod, Parapercis colias, in Foveaux Strait, New Zealand. - Aquatic Conservation: Marine and Freshwater Ecosystems 14: 491-504.

[7] Christiansen, T., Christensen, T.J., Markager, S., Petersen, J.K., Mouritsen, L.T. (2006): Limfjorden i 100 år. Klima, hydrografi, næringsstoftilførsel, bundfauna og fisk i Limfjorden fra 1897 til 2003. Scientific Report no. 578. National Environmental Research Institute, Denmark. In Danish.

[8] Dolmer, P., Christensen, H., Hansen, B., Vismann, B. (2012): Area-intensive bottom culture of blue mussels Mytilus edulis in a micro-tidal estuary. - Aquaculture Environment Interactions 3: 81-91.

[9] Dolmer, P., Frandsen, R. (2002): Evaluation of the Danish mussel fishery: suggestions for an ecosystem management approach. - Helgoland Marine Research 56: 13-20.

[10] EEA (1999): Environment in the European Union at the turn of the century. State of environment report, 1/1999. European Environment Agency. Copenhagen, Denmark.

[11] Eigaard, O.R., Støttrup, J., Hovgård, H. (2000): Udvikling af standard garnserie til brug ved rutinemæssig bestandsanalyse af flad- og rundfisk i marine lavvandede områder. Scientific report no. 78. Danish Institute for Fisheries Research. Charlottenlund, Denmark. In Danish.

[12] Fjøsne, K., Gjøsæter, J. (1996): Dietary composition and the potential of food competition between 0-group cod (Gadus morhua L.) and some other fish species in the littoral zone. - ICES Journal of Marine Science 53: 757-770.

[13] Gjøsaeter, J. (2002): Distribution and density of goldsinny wrasse (Ctenolabrus rupestris) (Labridae) in the Risør and Arendal areas along the Norwegian Skagerrak coast. - Sarsia 87: 75-82.

[14] Grese, R.E., Kaplan, R., Ryan, R.L., Buxton, R. (2000): Psychological benefits of volunteering in stewardship programs. - In: Gobster, P.H., Hull, B. (eds) Restoring nature: perspectives from the social sciences and humanities. Island Press, Wahington D.C., p 265-280.

[15] Hansen, K.S. (2012): Small scale distribution of fish in offshore wind farms. Master thesis report in Biology. University of Copenhagen and Technical University of Denmark, Charlottenlund, Denmark.

[16] Heck, K.J., Wetstone, G. (1977): Habitat complexity and invertebrate species richness and abundance in tropical seagrass meadows. - Journal of Biogeography 4: 135-142.

[17] Holm, P. (2005): Human impacts on fisheries resources and abundance in the Danish Wadden Sea, c1520 to the present. - Helgoland Marine Research 59: 39-44.

[18] IPCC (2014): Climate Change 2014. Fifth Assessment Synthesis Report. Intergovernmental Panel on Cliamte Change. Copenhagen, Denmark. 
[19] Jones, D., Clare, J. (1977): Annual and long-term fluctuations in the abundance of fish species inhabiting an intertidal mussel bed in Morecambe Bay, Lancashire. - Zoological Journal of the Linnean Society 60: 117-172.

[20] Kaiser, M., Clarke, K., Hinz, H., Austen, M., Somerfield, P., Karakassis, I. (2006): Global analysis of response and recovery of benthic biota to fishing. - Marine Ecology Progress Series 311: 1-14.

[21] Karlsen, J.D. (2011): Hot on the tail of hefty Atlantic cod: an interdisciplinary study on the behaviour at ship wrecks in the North Sea. Dissertation. Aarhus University and Technical University of Denmark. Denmark.

[22] Krause-Jensen, D., Carstensen, J., Nielsen, S.L., Dalsgaard, T., Christensen, P.B., Fossing, H., Rasmussen, M. (2011): Sea bottom characteristics affect depth limits of eelgrass Zostera marina. - Marine Ecology Progress Series 425: 91-102.

[23] Krause-Jensen, D., Markager, S., Dalsgaard, T. (2012): Benthic and pelagic primary production in different nutrient regimes. - Estuaries and Coasts 35: 527-545.

[24] Lindholm, J., Auster, P., Knight, A. (2007): Site fidelity and movement of adult Atlantic cod Gadus morhua at deep boulder reefs in the western Gulf of Maine, USA. - Marine Ecology Progress Series 342: 239-247.

[25] Luckhurst, B.E., Luckhurst, K. (1978): Analysis of the influence of substrate variables on coral reef fish communities. - Marine Biology 49: 317-323.

[26] Mackenzie, C.L., Lynch, S.A., Culloty, S.C., Malham, S.K. (2014): Future oceanic warming and acidification alter immune response and disease status in a commercial shellfish species, Mytilus edulis L. - PloS One 9 (6): e99712

[27] McDermott, S., Burdick, D., Grizzle, R., Greene, J. (2008): Restoring ecological functions and increasing community awareness of an urban tidal pond using blue mussels. - Ecological Restoration 26: 254-262.

[28] Nelson, W.G., Bonsdorff, E. (1990): Fish predation and habitat complexity: are complexity thresholds real? - Journal of Experimental Marine Biology and Ecology 141: 183-194.

[29] Newell, R., Koch, E. (2004): Modeling seagrass density and distribution in response to changes in turbidity stemming from bivalve filtration and seagrass sediment stabilization. - Estuaries 27: 793-806.

[30] Nielsen, T., Maar, M. (2007): Effects of a blue mussel Mytilus edulis bed on vertical distribution and composition of the pelagic food web. Marine Ecology Progress Series 339: 185-198

[31] Nielsen, P.E., Petersen, E.H. (2013): Råstofproduktion i Danmark. Havområdet 2012. Scientific Report. Nature Agency, Danish Ministry of the Environment, Copenhagen, Denmark. In Danish.

[32] Nielsen, S.L., Sand-Jensen, K., Borum, J., Geertz-Hansen, O. (2002): Depth colonization of eelgrass (Zostera marina) and macroalgae as determined by water transparency in Danish coastal waters. - Estuaries 25: 1025-1032.

[33] Norling, P., Kautsky, N. (2007): Structural and functional effects of Mytilus edulis on diversity of associated species and ecosystem functioning. - Marine Ecology Progress Series 351: 163-175.

[34] Norling, P., Kautsky, N. (2008): Patches of the mussel Mytilus sp. are islands of high biodiversity in subtidal sediment habitats in the Baltic Sea. - Aquatic Biology 19: 75-87.

[35] Palomo, M., People, J., Chapman, M., Underwood, A. (2007): Separating the effects of physical and biological aspects of mussel beds on their associated assemblages. - Marine Ecology Progress Series 344: 131-142.

[36] Petersen, J., Maar, M., Ysebaert, T., Herman, P. (2013): Near-bed gradients in particles and nutrients above a mussel bed in the Limfjorden: influence of physical mixing and mussel filtration. - Marine Ecology Progress Series 490: 137-146.

[37] Petersen, J.K., Timmermann, K., Holmer, M., Hasler, B.E., Cordula, G., Marianne, Z. (2013): Miljømuslinger. Muslinger som supplerende virkemiddel. Notat fra DCE - 
Nationalt Center for Miljø og Energi. Scientific Report. University of Aarhus and Danish Nature Agency, Danish Ministry of the Environment. Denmark. In Danish.

[38] Peterson, C., Grabowski, J., Powers, S. (2003): Estimated enhancement of fish production resulting from restoring oyster reef habitat: quantitative valuation. - Marine Ecology Progress Series 264: 249-264.

[39] Pihl, L., Modin, J., Wennhage, H. (2005): Relating plaice (Pleuronectes platessa) recruitment to deteriorating habitat quality: effects of macroalgal blooms in coastal nursery grounds. - Canadian Journal of Fisheries and Aquatic Sciences 62: 1184-1193.

[40] Rask, N., Madsen, H.B., Larsen, S. (2000): Vandmiljøovervågning. Kystvande 1999. Miljø- og Arealafdelingen og Natur og Vandmiljøafdelingen, Fyns Amt. Scientific Report. Odensen, Denmark. In Danish.

[41] Riemann, B., Nielsen, T., Horsted, S., Bjørnsen, P., Pock-Steen, J. (1988): Regulation of phytoplankton biomass in estuarine enclosures. - Marine Ecology Progress Series 48: 205-215.

[42] Seitz, R.D., Wennhage, H., Bergström, U., Lipcius, R.N., Ysebaert, T. (2014): Ecological value of coastal habitats for commercially and ecologically important species. - ICES Journal of Marine Science 71: 648-665.

[43] Sundblad, G., Bergström, U., Sandström, A., Eklöv, P. (2014): Nursery habitat availability limits adult stock sizes of predatory coastal fish. - ICES Journal of Marine Science 71: 672-680.

[44] Underwood, A.J. (1992): Beyond BACI: the detection of environmental impacts on populations in the real, but variable, world. - Journal of Experimental Marine Biology and Ecology 161: 145-178.

[45] Wennhage, H., Pihl, L. (2002): Fish feeding guilds in shallow rocky and soft bottom areas on the Swedish west coast. - Journal of Fish Biology 61: 207-228.

[46] Wilhelmsson, D., Yahya, S.A.S., Öhman, M.C. (2006): Effects of high-relief structures on cold temperate fish assemblages: A field experiment. - Marine Biology Research 2: $136-147$.

[47] Winter, J.E. (1973): The filtration rate of Mytilus edulis and its dependence on algal concentration, measured by a continuous automatic recording apparatus. - Marine Biology 22: 317-328.

[48] Wulff, F., Humborg, C., Andersen, H.E., Blicher-Mathiesen, G., Czajkowski, M., Elofsson, K., Fonnesbech-Wulff, A., Hasler, B., Hong, B., Jansons, V., Mörth, C.M., Smart, J.C.R., Smedberg, E., Stålnacke, P., Swaney, D.P., Thodsen, H., Was, A., Zylicz, T. (2014): Reduction of Baltic Sea nutrient inputs and allocation of abatement costs within the Baltic Sea catchment. - Ambio 43: 11-25. 